\title{
Human Milk-Derived Oligosaccharides and Plant-Derived Oligosaccharides Stimulate Cytokine Production of Cord Blood T-Cells In Vitro
}

\author{
THOMAS EIWEGGER, BERND STAHL, JOACHIM SCHMITT, GÜNTHER BOEHM, \\ MARIANNE GERSTMAYR, JOSEFA PICHLER, ELEONORA DEHLINK, CHRISTINE LOIBICHLER, \\ RADVAN URBANEK, AND ZSOLT SZÉPFALUSI \\ Department of Pediatrics and Juvenile Medicine [T.E., M.G., J.P., E.D., C.L., R.U., Z.S.], University of \\ Vienna, Medical School, A-1090 Vienna, Austria; and Numico Research Germany [B.S., J.S., G.B.], \\ GER-61381 Friedrichsdorf, Germany
}

\begin{tabular}{|c|c|}
\hline \multicolumn{2}{|c|}{ ABSTRACT } \\
\hline $\begin{array}{l}\text { Human milk contains large amounts of free oligosaccharides } \\
\text { (HMOs). HMOs have been shown to exert antiinflammatory } \\
\text { properties, and evidence for their immunomodulatory effects is } \\
\text { increasing. The purpose of this study was to evaluate influences } \\
\text { of two human breast milk-derived oligosaccharide samples } \\
\text { (neutral and acidic oligosaccharides), and of a low-molecular- } \\
\text { weight fucoidan on cytokine production and activation of cord } \\
\text { blood mononuclear cells. Cord blood mononuclear cells from } \\
\text { randomly chosen healthy newborns were co-cultured with the } \\
\text { oligosaccharide samples. By means of flow cytometry, intracel- } \\
\text { lular cytokine production (d 20) and surface marker expression } \\
\text { of T cells (d 5) were measured. In vitro-induced Ig levels were } \\
\text { quantified nephelometrically (total IgG1) and by ELISA (total } \\
\text { IgE) in the supernatant of cell cultures. The acidic oligosaccha- } \\
\text { ride fraction increased the percentage of interferon- } \gamma \text { producing } \\
\text { CD3+CD4+ and CD3 }+ \text { CD8+ cells }(p<0.05) \text { and the IL-13 } \\
\text { production in CD3+CD8+ cells }(p<0.05) \text { In acidic oligosac- } \\
\text { charide cultures, CD25+ expression on CD3+CD4+ cells was } \\
\text { significantly elevated ( } p<0.05 \text { ). Low-molecular-weight fu- }\end{array}$ & $\begin{array}{l}\text { coidan induced IL-4 production in CD3 }+\mathrm{CD} 4+\mathrm{T} \text { cells }(p< \\
0.05) \text { and IL-13 production in CD } 3+\mathrm{CD} 8+\mathrm{T} \text { cells }(p<0.05) \text {, } \\
\text { whereas interferon- } \gamma \text { production remained unaffected in both } \\
\text { T-cell populations. Ig production (total IgE and total IgG1) } \\
\text { remained unaffected. Human milk-derived oligosaccharides and } \\
\text { plant-derived oligosaccharides affect the cytokine production and } \\
\text { activation of cord blood derived T cells in vitro. Therefore, } \\
\text { oligosaccharides and, in particular, acidic oligosaccharides may } \\
\text { influence lymphocyte maturation in breast-fed newborns. } \\
\text { (Pediatr Res 56: 536-540, 2004) } \\
\text { Abbreviations } \\
\text { aHMOs, acidic oligosaccharides } \\
\text { CBMC, cord blood mononuclear cells } \\
\text { HMOs, human milk oligosaccharides } \\
\text { LMWF, low-molecular-weight fucoidan } \\
\text { nHMOs, neutral oligosaccharides } \\
\text { PHA, phytohemagglutinin } \\
\text { PMA, phorbol myristate acetate }\end{array}$ \\
\hline
\end{tabular}

The postnatal period is a crucial time for the maturation of the immune system. At birth, T-lymphocytes exhibit a Th2profile, characterized by a limited ability to produce cytokines. Throughout the first months after birth these Th2-skewed responses are modified into low-level immunity, predominantly expressing Th1-cytokines and IgG-antibodies, particularly of the IgG1 subclass $(1,2)$.

Human milk is a biologic fluid containing large amounts of free oligosaccharides. HMOs represent the third largest solid

\footnotetext{
Received March 12, 2003; accepted August 4, 2003.

Correspondence: Zsolt Szépfalusi, M.D., Department of Pediatrics, AKH-Vienna, Waehringer Guertel 18-20, A-1090 Vienna, Austria; e-mail: Zsolt.Szepfalusi@akh-wien.ac.at Supported by the BMBF-Fonds $0311827 \mathrm{~A} / \mathrm{B} / \mathrm{C}$ and the FWF-grant (P1465-PAT).

DOI: 10.1203/01.PDR.0000139411.35619.B4
}

component (after lactose and lipids) in breast milk, occurring at a concentration of $20-23 \mathrm{~g} / \mathrm{L}$ in colostrum and $12-14 \mathrm{~g} / \mathrm{L}$ in mature milk (3). HMOs are very resistant to enzymatic hydrolysis $(4,5)$, indicating that these oligosaccharides must display essential nonnutritive functions.

Throughout the last decade, numerous studies demonstrated the ability of HMOs to inhibit pathogens acting as receptors for microbes $(6,7)$. Only a few reports on direct effects on immune function have been published so far. Human milk oligosaccharide structures like lacto- $N$-fucopentaose III (LNFPIII) and lacto- $N$-neotetraose (LNneoT) showed an effect on murine IL-10 production (8). It is further discussed that human milk is involved in the generation of antiinflammatory mediators that suppress Th1-type and inflammatory responses in mice (9). 
The interaction of HMOs with selectins in cell-cell interactions of, for example, leukocytes and lymphocytes was recently described by Rudloff et al. (10). Due to their resistance to enzymatic hydrolysis, HMOs can be absorbed and cross the brush border membrane of the intestine $(6,11,12)$. This suggests that HMOs may act systemically and that their properties are not restricted to the intestinal mucosal environment.

So far, little is known about whether human milk-derived oligosaccharides are able to exert direct effects on cytokine production and activation/maturation of CBMC. In the present experiment, the capability of two different fractions of HMOs and LMWF, as an example of plant-derived oligosaccharides, to exert direct effects on function and maturation of CBMC in vitro were studied. Such data could help us to understand whether dietary oligosaccharides can directly influence the postnatal development of the immune system.

\section{MATERIALS AND METHODS}

Preparation of test substances. Pooled human milk was delipidated by centrifugation at $45^{\circ} \mathrm{C}$ using a separator (Elecrem 3, Häka, Stutensee-Friedrichstal, Germany). The proteins were precipitated by ethanol (final concentration 66\%), as described by Kobata (13). The precipitated proteins were removed by using a separator (Westfalia, Oelde, Germany) at $4^{\circ} \mathrm{C}$ and the liquid phase was concentrated by evaporation at 20 mbar (Heidolph, Schwabach, Germany) by a factor of three and subsequently freeze dried (Christ, Osterode, Germany).

An aliquot of the resulting carbohydrate/mineral fraction was filtered using a $0.3 \mu \mathrm{m}$ membrane (Omega; Pall Filtron, Dreieich, Germany) and further applied to simulated moving bed chromatography (SMB). SMB was chosen to remove the excess of lactose and the monosaccharides from the oligosaccharides of interest. The SMB system was a Licosep-Lab 12-26 1040 (NovaSep, Nancy, France). The separation was performed with 10 columns $(2.5 \times 53 \mathrm{~cm}$; Kronlab, Sinsheim, Germany) operated at $55^{\circ} \mathrm{C}$ with Toyopearl HW 40 (C) (TosoHaas, Stuttgart, Germany) as stationary phase. Demineralized water served as eluent (14). The raffinate containing the oligosaccharides was analyzed by high-performance anion exchange chromatography (HPAEC), concentrated, and freeze dried. An aliquot of $1.3 \mathrm{~g}$ oligosaccharides was dissolved in $5 \mathrm{~mL}$ water and was applied to gel permeation chromatography (GPC). The GPC was performed on two Toyopearl HW 40 (S) columns (5 $\times 110 \mathrm{~cm}$, TosoHaas). The acidic and the neutral fraction of oligosaccharides, respectively, were eluted with $2 \%$ ( $\mathrm{vol} / \mathrm{vol})$ isopropanol in demineralized water (flow rate of $1.65 \mathrm{~mL} / \mathrm{min}$ ) and monitored by refractive index detection, as described previously $(15,16)$. Both fractions were analyzed by HPAEC (Fig. 1), concentrated, and freeze dried for further analyses.

LMWF (Kraeber GmbH \& Co; Ellerbek, Germany) was extracted from brown seaweed (mainly Ascophyllum nodosum) and depolymerized by a radical method with hydrogen peroxide. The molecules consisted mainly of alpha glycosidic linked fucose partly sulfated as well as uronic acids and neutral sugars like galactose and xylose residues. The average molecular weight was about $8.2 \mathrm{kD}$, with a content of fucose $28 \%$, uronic acid $16 \%$, and sulfate $23 \%$ dry matter, respectively. For more

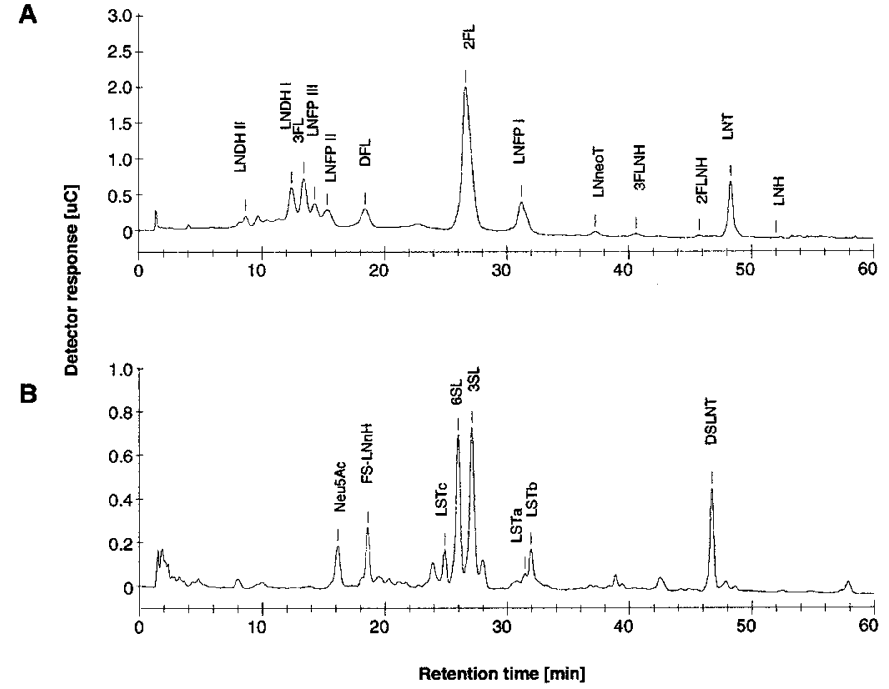

Figure 1. HPAEC profiles of nHMOs and aHMOs. For used abbreviations and chromatographic conditions see (16). 3-FL, 3-fucosyllactose; LNFP, Lacto-N-fucopentaoses I-III; 2-FL, 2-fucosyllactose; LNH, Lacto-N-hexose; LNT, Lacto-N-tetraose; 2FLNH, 2-fucosyllacto-N-hexaose; 3FLNH, 3-fucosyllacto-N-hexaose; LNneoT, Lacto-N-neotetraose; DFL, difucosyllactose; LNDH I-II, Lacto-N-difucosyl-hexoases I-II; Neu5Ac, N-acetylneuraminic acid (sialic acid); FS-LNnH, fucosyl-sialyl-lacto-N-neohexaoses; LSTc, Lactosialyl-tetrasaccharide a-c; 6SL, 6-sialyllactose; 3SL, 3-sialyllactose; DSLNT, disialyl-lacto-N-tetraose.

detailed information on the preparation of LMWF, the reader is referred to ref. 17.

To separate oligosaccharides that have the same number, type, sequence, and anomeric configuration of monosaccharides while differing in the linkage position of a single monomer high-pH anion exchange, chromatography with pulsed amperometric detection (HPAEC-PAD) was applied. HPAEC analyses were performed on a DX-300 Bio-LC-system (Dionex, Idstein, Germany) with a pulsed electrochemical detector (PED 2, Dionex). Twenty-five microliter aliquots of samples were loaded on a CarboPac PA-100 (Dionex) pellicular anionexchange column $(4 \times 250 \mathrm{~mm})$ equipped with a guard column $(4 \times 50 \mathrm{~mm})$ and separated at a flow-rate of $1 \mathrm{~mL} / \mathrm{min}$. The concentration of the oligosaccharide fractions applied was 1-2 $\mathrm{g} / \mathrm{L}$. Neutral and acidic oligosaccharides were analyzed using gradient conditions as described previously (15).

Analysis of neutral oligosaccharides was performed with a two-layer matrix. One microliter of 5-chloro-2-mercaptobenzothiazol (CMBT) solution $(10 \mathrm{~g} / \mathrm{L}$ in tetrahydrofuran/ ethanol/deionized water; $1: 1: 1 ; \mathrm{vol} / \mathrm{vol} / \mathrm{v}$ ) was applied to the target and dried in a cold, strong stream of air. On top of the microcrystalline CMBT layer, $1 \mu \mathrm{L}$ of analyte (typically $1 \mathrm{~g} / \mathrm{L}$ ) and $1 \mu \mathrm{L}$ of 2.5 -dihydroxybenzoic acid (DHB) solution (20 $\mathrm{g} / \mathrm{L}$ dissolved in deionized water) were placed and air-dried again (18). The matrix used for acidic oligosaccharides was 6-aza-2-thiothymine (ATT) (1 g/L dissolved in ethanol) with the addition $(1: 1 ; \mathrm{vol} / \mathrm{vol})$ of an aqueous diammonium hydrogen citrate (DAHC) solution $(20 \mathrm{mM})$ according to Papac et al. (19). The analyte/matrix mixture was directly applied onto the stainless steel target and air-dried. Endotoxin levels of all three substances were measured thereafter to ensure pyrogen levels appropriate for cell culture (20). 
CBMC preparation and culture conditions. Human umbilical cord blood from randomly chosen full-term healthy infants ( $>37$ wk of gestation) was obtained by venipuncture of the umbilical vein immediately after delivery and placed in sterile sodium heparin tubes. Heparinized cord blood was drawn over Ficoll-Paque (Pharmacia, Uppsala, Sweden). CBMC were isolated by density-gradient centrifugation as described $(21,22)$. The protocol was approved by the local ethical committee of the University of Vienna.

To evaluate the optimal antigen concentrations within a range mimicking physiologic conditions $(3,11,23,24)$ and to exclude possible cytotoxic effects of the investigated substances on CBMC, proliferation assays were performed as previously described $(21,22,25)$. Because neither cytotoxic effects nor a significant proliferative response were detected, nHMOs and LMWF were applied at a concentration of 10 $\mu \mathrm{g} / \mathrm{mL}$ and aHMOs at $1 \mu \mathrm{g} / \mathrm{mL}$. LMWF served as a control substance for a plant-derived oligosaccharide with a comparable molecular weight $(\sim 8 \mathrm{kD})$ and was therefore applied within the same concentration range $(10 \mu \mathrm{g} / \mathrm{mL})$.

As recently evaluated within another study on the effects of vitamin D (26), we found a co-culture time of $20 \mathrm{~d}$ to be optimal for intracellular cytokine detection by flow cytometry in CBMC. Based on the assumption that HMOs are not acting in antigen-like fashion but may have an influence on cell maturation and cytokine production, we applied the same culture conditions. To evaluate influences of the OS samples on surface marker expression under unstimulated culture conditions, $\mathrm{d} 5$ turned out to be the most efficient endpoint assuring viability of the investigated cells. This is also consistent with data from Viemann et al. (27).

For long-term cell cultures ( $20 \mathrm{~d}), \mathrm{CBMC}$ were adjusted at a concentration of $10^{6}$ cells per milliliter medium UCC in culture flasks (Costar, Cambridge, MA). PHA (Invitrogen, Carlsbad, CA) was supplemented at a concentration of $1 \%$ $\mathrm{vol} / \mathrm{vol}$ for the first $3 \mathrm{~d}$ and replaced by IL-2 $(20 \mathrm{IU} / \mathrm{mL}$, Roche Diagnostics GmbH, Basel, Switzerland) on d 3 to maintain cell proliferation and cell viability $(26,28)$. On d 3,7 , and 14 , cells were washed once, counted, and $10^{6}$ cells per milliliter were restimulated with antigen and IL-2. IL-2 alone served as control. On d 10 and 17, fresh medium (UCC) was added.

For all other experiments CBMC $\left(10^{6} / \mathrm{mL}\right)$ were cultured in RPMI 1640 medium supplemented with $2 \mathrm{mM}$ L-glutamine, 85 $\mathrm{mg} / \mathrm{L}$ gentamicin-sulphate (all from Sigma Chemical Co., St. Louis, MO) and 10\% heat-inactivated FCS (Invitrogen). The oligosaccharide samples were added in the above mentioned concentrations. Medium alone served as control.

Flow cytometric analysis. On d 20, the percentage of cytokine-producing $\mathrm{CD} 4+$ and $\mathrm{CD} 8+\mathrm{T}$ cells was analyzed by intracellular cytokine detection. Expression of the Th1cytokines interferon (IFN)- $\gamma$ and IL-6 and the Th2-cytokines IL-4, IL-10, and IL-13 was assessed with MAb and four-color flow cytometry (FACSCalibur, BD Bioscience, San Jose, CA). The technique has been described previously $(29,30)$. Cells were stimulated with $10 \mathrm{ng} / \mathrm{mL}$ phorbol myristate-acetate (PMA) and $1.25 \mu \mathrm{M}$ ionomycin, in the presence of $2 \mu \mathrm{M}$ monensin (all from Sigma Chemical Co.). After $4 \mathrm{~h}$, cells were harvested, washed, and fixed with $2 \%$ formaldehyde.
Four-color fluorescence staining was performed using rat or mouse anti-human MAb and the respective isotype controls labeled with FITC, phycoerythrin (PE), peridin chlorophyll (PerCP), allophycocyanin (APC): anti-CD19 (FITC) (DAKO, Glostrup, Denmark), anti-CD3 (PerCP, APC), anti-CD4 (FITC, APC), anti-CD8 (PE, PerCP), anti-CD22 (PE), antiCD25 (APC), anti-HLA-DR (APC), anti-IFN- $\gamma$ (FITC, PE), anti-IL-4 (PE), anti-IL-13 (PE) (all from BD Biosciences), anti-IL-6 (PE), anti-IL-10 (PE) (from BD PharMingen, San Diego, CA).

In vitro production of $\mathbf{I g}$. At $\mathrm{d} 1,5$, and $10, \operatorname{IgG} 1$ and $\operatorname{IgE}$ were measured by nephelometry (IgG1, IMMAGE, Beckman Coulter, Fullerton, CA; limit of detection $6 \mu \mathrm{g} / \mathrm{mL}$ ) and $\operatorname{IgE}$ Sandwich-ELISA (Kallestad Total-IgE microplate, Bio-Rad, Munich, Germany; limit of detection $1 \mathrm{ng} / \mathrm{mL}$ ). IL-4 (200 $\mathrm{IU} / \mathrm{mL})$ and anti-CD40 MAb $(0.2 \mu \mathrm{g} / \mathrm{mL})$ (BD PharMingen) was added to the positive control, medium alone and CBMC was used as negative control. All investigations were performed simultaneously, with and without preactivation of $\mathrm{T}$ cells with plate-bound anti-CD3-MAb (DAKO).

Statistics. For independent, nonparametric comparison of IgG1 and IgE levels with the respective control, MannWhitney $U$ test was used. To detect significant changes of IgG1 and IgE production over the course of cell culture, KruskalWallis test was used. For all other experiments, Wilcoxon signed-rank test was applied. For all analyses, SPSS for Windows Release 11.0.1 (SPPS Inc., Chicago, IL) was used. $p$ Values of $<0.05$ were considered significant.

\section{RESULTS}

Influences of oligosaccharides on T-cell function. In longterm cell culture experiments, levels of the cytokines IL-4, IL-13, and IFN- $\gamma$ were detected and used for statistical evaluation. Because the amount of $\mathrm{T}$ cells staining positive for intracellular IL-6 and IL-10 was very low ( $<1 \%$ of the respective T-cell subpopulation), or not detectable, these two cytokines were excluded from statistical evaluation.

nHMOs had little or no influence on intracellular cytokine production (Fig. 2). In the presence of the aHMOs and the LMWF, several effects on T-cell cytokine production were detectable (Fig. 2). aHMOs lead to a significant rise in the percentage of IFN- $\gamma$-producing CD4+ and CD8 + T cells and of IL-13 production in CD8 + T cells. In contrast, LMWF did not affect IFN- $\gamma$ production in CD4 + T cells. In CD8 + T cells, there was a trend toward a reduction of IFN- $\gamma$-producing cells ( $p=0.08)$ upon stimulation with LMWF. Moreover, LMWF increased the amount of IL-4-producing $\mathrm{CD} 3+\mathrm{CD} 4+$ cells and the percentage of IL-13-expressing CD3 $+\mathrm{CD} 8+$ cells significantly.

To evaluate whether the observed changes in cytokine production after long-term exposure to the investigated oligosaccharides were also reflected in an enhanced activation marker expression after $5 \mathrm{~d}$ in co-culture with oligosaccharides, we measured the percentage of CD4+CD25+ lymphocytes. Both, aHMOs and LMWF lead to a significant rise of CD25 expression (Fig. 3). This effect was not observed in the presence of the neutral oligosaccharide fraction (nHMOs) (Fig. 3). 

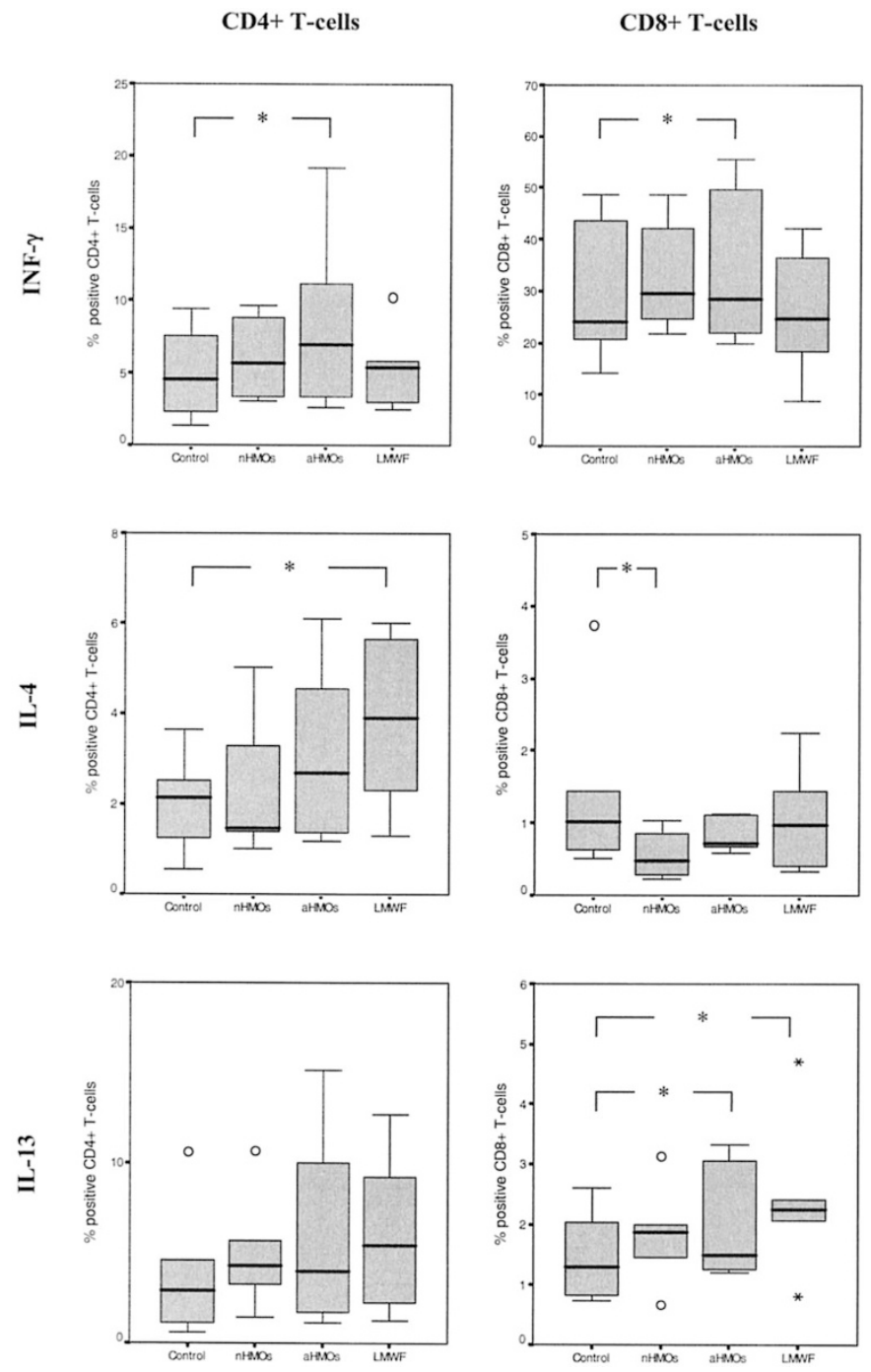

Figure 2. Intracellular cytokine production of cord blood-derived $\mathrm{T}$ cells. CBMC $\left(n=6,10^{6} / \mathrm{mL}\right)$ were co-cultured for $20 \mathrm{~d}$ with IL-2 and the respective oligosaccharide sample. Medium and IL-2 alone served as control. The percentage of IFN- $\gamma-$, IL-4-, and IL-13-producing CD4+ and CD8 + T cells was measured by means of flow cytometry. ${ }^{*} p<0.05 v s$ control.
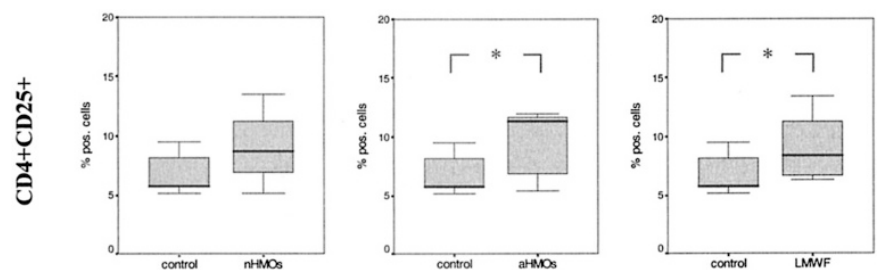

Figure 3. Percentage of CD25-expressing cord blood-derived CD4+ T cells. CBMC from randomly chosen full-term healthy infants $(n=6,>37$ wk of gestation) were cultured for $5 \mathrm{~d}$ in the presence of the respective oligosaccharide sample or medium alone. The percentage of CD25+ CD4+ cells was measured by means of flow cytometry. ${ }^{*} p<0.05 v s$ control.

Influences of oligosaccharides on B-cell function. Possible effects of the oligosaccharide samples on B cells were investigated via detection of changes in the mean fluorescence of CD22 and HLA-DR. Neither up- nor down-regulation of these markers in statistically significant ways could be observed (data not shown).
Upon stimulation with nHMOs, aHMOs, and LMWF, total IgG1 production was not affected (data not shown). Total IgE production was virtually absent (data not shown). In the positive control (IL-4 + anti CD40), IgE-levels ranged from 1 to $8 \mathrm{ng} / \mathrm{mL}$ (d 5) and 7 to $107 \mathrm{ng} / \mathrm{mL}$ (d 10).

\section{DISCUSSION}

To our knowledge, this is the first study that shows a direct influence of HMOs on cord blood-derived T cells in vitro from randomly selected term newborns. Although many investigations focused on the antiinflammatory properties of HMOs (6,31-33), no study has described an influence on human T-cell cytokine production in vitro so far.

Our experimental data indicate that the human milk-derived acidic oligosaccharide fraction (aHMOs) is able to enhance the production of certain cytokines after long-term exposure (20 d) in vitro in the $\mathrm{CD} 4+$ as well as in $\mathrm{CD} 8+\mathrm{T}$-cell subfraction (Fig. 2). The aHMO fraction stimulated an increase of IFN- $\gamma$ producing cells in both T-cell types. Furthermore, a shift toward induction of $\mathrm{Th} 0 / \mathrm{Tc} 0$ could be excluded (data not shown). Taken together, these data support the assumption that aHMOs increase T-cell cytokines in a Th1/Tc1-favoring manner. Nevertheless, IL-13-producing CD8 $+\mathrm{T}$ cells also increased significantly upon stimulation with aHMOs (Fig. 2). Due to the fact that IL-4 production remained unaffected by aHMOs, the effect on Tc2 cytokines could be assumed as minor. Further proof of a direct effect of the aHMOs on $\mathrm{T}$ cells was given by the fact that the amount of CD25+ CD4+ cells increased significantly in vitro in the presence of aHMOs (Fig. 3).

Breast milk-derived oligosaccharides were shown to cross the intestinal barrier to finally appear in the urine of infants $(6,11)$. According to these data, we have used concentrations within a range (nHMOs, $10 \mu \mathrm{g} / \mathrm{mL}$; aHMOs, $1 \mu \mathrm{g} / \mathrm{mL}$ ) mimicking physiologic conditions. The effect of these concentrations on cord blood $\mathrm{T}$ and $\mathrm{B}$ cells may therefore reflect physiologic levels occurring in very young infants during breast-feeding.

Concerning B-cell functions, no effects were induced by aHMOs. The herewith-documented effects on $\mathrm{T}$ cells were neither reflected by an enhanced B-cell activation marker expression nor in increased total-IgG1 or total-IgE production in vitro, thus leading to the conclusion that the observed effects were restricted to T cells. However, aHMO concentrations used in these experiments might not have been high enough to affect neonatal B cells.

Recent publications demonstrated that cord blood $\mathrm{T}$ cells in individuals developing subsequent atopic disease showed an allergen-specific Th2 profile and were generally reduced in their ability to produce IFN- $\gamma$ as well as Th2-cytokines (2,3436). Our data showed that aHMOs under in vitro conditions stimulate cord blood $\mathrm{T}$ cells toward an enhanced ability of IFN- $\gamma$ as well as Th2-cytokine production. This might indicate that absorbed aHMOs during breast-feeding may play a direct role in the postnatal maturation of the immune system and may posses allergy-preventive functions.

The LMWF, which was used in the study protocol as an example of a plant-derived oligosaccharide with the potential 
to be used in infant formulas, affected T-cell cytokine production in a Th2-favoring manner in vitro (Fig. 2). This was supported, first, by the significantly increased percentage of IL-4 - and IL-13-producing cells upon stimulation with LMWF and, secondly, by the trend of a diminished IFN- $\gamma$ production (not statistically significant), which was stronger in the CD8 + T-cell population $(p=0.08)$. The observed influences of LMWF on T-cell cytokine synthesis were strengthened by the fact that the percentage of $\mathrm{CD} 25$-expressing $\mathrm{CD} 4+$ $\mathrm{T}$ cells in 5-d cultures increased significantly compared with the control. LMWF may, in summary, promote a Th2 profile in $\mathrm{T}$ cells. Thus, more detailed research in this field is needed to exclude the possibility that LMWF may have an allergypromoting function.

Although CD25 was used in the context of this study clearly as an activation marker of $\mathrm{T}$ cells, the possibility of an induction of CD4+CD25+ regulatory cells by oligosaccharides has to be taken into consideration, but cannot be answered by the present study. An important aspect in this context was the fact that B-cell activation marker expression and the production of Th2-associated IgE was not affected in vitro by any of the applied oligosaccharides. However, for several reasons, conclusions for effects in vivo have to be made with caution. A very strong stimulus is necessary to achieve a switch of Ig production toward IgE production in vitro (37). Another reason may be a mode of action, to date unknown, affecting only $\mathrm{T}$ cells.

In conclusion, the assumption that oligosaccharides are able to modulate the immune system of the maturing infant is given further support by our data. Based on our data, it is evident that different oligosaccharide structures have different direct effects on the immune system, indicating that HMOs provide a great variety of effects on the developing immune system during infancy. The implication of these findings for the composition of infant formulae needs further investigation.

\section{REFERENCES}

1. Holt PG, Jones CA 2000 The development of the immune system during pregnancy and early life. Allergy 55:688-697

2. Prescott SL, Macaubas C, Smallacombe T, Holt BJ, Sly PD, Holt PG 1999 Development of allergen-specific T-cell memory in atopic and normal children. Lancet 353:196-200

3. Coppa GV, Pierani P, Zampini L, Carloni I, Carlucci A, Gabrielli O 1999 Oligosaccharides in human milk during different phases of lactation. Acta Paediatr Suppl 88:89-94

4. Engfer MB, Stahl B, Finke B, Sawatzki G, Daniel H 2000 Human milk oligosaccharides are resistant to enzymatic hydrolysis in the upper gastrointestinal tract. Am J Clin Nutr 71:1589-1596

5. Gnoth MJ, Kunz C, Kinne-Saffran E, Rudloff S 2000 Human milk oligosaccharides are minimally digested in vitro. J Nutr 130:3014-3020

6. Kunz C, Rudloff S, Baier W, Klein N, Strobel S 2000 Oligosaccharides in human milk: structural, functional, and metabolic aspects. Annu Rev Nutr 20:699-722

7. Newburg DS 2001 Bioactive components of human milk: evolution, efficiency, and protection. Adv Exp Med Biol 501:3-10

8. Velupillai P, Harn DA 1994 Oligosaccharide-specific induction of interleukin 10 production by $\mathrm{B} 220+$ cells from schistosome-infected mice: a mechanism for regulation of CD4+ T-cell subsets. Proc Natl Acad Sci U S A 91:18-22

9. Terrazas LI, Walsh KL, Piskorska D, McGuire E, Harn DA 2001 The schistosome oligosaccharide lacto- $N$-neotetraose expands $\operatorname{Gr} 1(+)$ cells that secrete antiinflammatory cytokines and inhibit proliferation of naive $\mathrm{CD} 4(+)$ cells: a potential mechanism for immune polarization in helminth infections. J Immunol 167:52945303

10. Rudloff S, Stefan C, Pohlentz G, Kunz C 2002 Detection of ligands for selectins in the oligosaccharide fraction of human milk. Eur J Nutr 41:85-92

11. Obermeier S, Rudloff S, Pohlentz G, Lentze MJ, Kunz C 1999 Secretion of ${ }^{13} \mathrm{C}$ labelled oligosaccharides into human milk and infant's urine after an oral $\left[{ }^{13} \mathrm{C}\right]$ galactose load. Isotopes Environ Health Stud 35:119-125

12. Gnoth MJ, Rudloff S, Kunz C, Kinne RK 2001 Investigations of the in vitro transport of human milk oligosaccharides by a Caco-2 monolayer using a novel high performance liquid chromatography-mass spectrometry technique. J Biol Chem 276:3436334370

13. Kobata A 1973 [Biochemical basis for blood groups]. Tanpakushitsu Kakusan Koso 18:83-92

14. Finke B 2000 Isolierung und Charakterisierung von Oligosacchariden aus humanen und tierischen Milchen. Shaker Verlag, Aachen, Germany

15. Thurl S, Muller-Werner B, Sawatzki G 1996 Quantification of individual oligosaccharide compounds from human milk using high-pH anion-exchange chromatography. Anal Biochem 235:202-206

16. Finke B, Mank M, Daniel H, Stahl B 2000 Offline coupling of low-pressure anion-exchange chromatography with MALDI-MS to determine the elution order of human milk oligosaccharides. Anal Biochem 284:256-265

17. Deux JF, Meddahi-Pelle A, Le Blanche AF, Feldman LJ, Colliec-Jouault S, Bree F, Boudghene F, Michel JB, Letourneur D 2002 Low molecular weight fucoidan prevents neointimal hyperplasia in rabbit iliac artery in-stent restenosis model. Arterioscler Thromb Vasc Biol 22:1604-1609

18. Pfenninger A, Karas M, Finke B, Stahl B, Sawatzki G 1999 Matrix optimization for matrix-assisted laser desorption/ionization mass spectrometry of oligosaccharides from human milk. J Mass Spectrom 34:98-104

19. Papac DI, Wong A, Jones AJ 1996 Analysis of acidic oligosaccharides and glycopeptides by matrix-assisted laser desorption/ionization time-of-flight mass spectrometry. Anal Chem 68:3215-3223

20. Gnoth MJ, Kunz C, Rudloff S 2000 Endotoxin-reduced milk oligosaccharide fractions suitable for cell biological studies. Eur J Med Res 5:468-472

21. Szepfalusi Z, Nentwich I, Gerstmayr M, Jost E, Todoran L, Gratzl R, Herkner K, Urbanek R 1997 Prenatal allergen contact with milk proteins. Clin Exp Allergy 27:28-35

22. Kopp MV, Pichler J, Halmerbauer G, Kuehr J, Frischer T, Urbanek R, Szepfalusi Z 2000 Culture conditions for the detection of allergen-specific T-cell reactivity in cord blood: influence of cell number. Pediatr Allergy Immunol 11:4-11

23. Bode L, Rudloff S 2001 Mögliche systemische Effekte von Humanmilcholigosacchariden (Hmo) — ein in vitro Modell. Monatsschr Kinderheilkd 149:132

24. Rudloff S, Pohlentz G, Diekmann L, Egge H, Kunz C 1996 Urinary excretion of lactose and oligosaccharides in preterm infants fed human milk or infant formula. Acta Paediatr 85:598-603

25. Miles EA, Warner JA, Lane AC, Jones AC, Colwell BM, Warner Jo 1994 Altered T lymphocyte phenotype at birth in babies born to atopic parents. Pediatr Allergy Immunol 5:202-208

26. Pichler J, Gerstmayr M, Szepfalusi Z, Urbanek R, Peterlik M, Willheim M 20021 alpha,25(OH)2D3 inhibits not only Th1 but also Th2 differentiation in human cord blood T cells. Pediatr Res 52:12-18

27. Viemann D, Schlenke P, Hammers HJ, Kirchner H, Kruse A 2000 Differential expression of the B cell-restricted molecule CD22 on neonatal B lymphocytes depending upon antigen stimulation. Eur J Immunol 30:550-559

28. Gehring S, Schlaak M, van der Bosch J 1998 A new in vitro model for studying human $\mathrm{T}$ cell differentiation: $\mathrm{T}(\mathrm{h} 1) / \mathrm{T}(\mathrm{h} 2)$ induction following activation by superantigens. J Immunol Methods 219:85-98

29. Jung T, Schauer U, Heusser C, Neumann C, Rieger C 1993 Detection of intracellular cytokines by flow cytometry. J Immunol Methods 159:197-207

30. Prussin C, Metcalfe DD 1995 Detection of intracytoplasmic cytokine using flow cytometry and directly conjugated anti-cytokine antibodies. J Immunol Methods 188:117-128

31. Coppa GV, Gabrielli O, Giorgi P, Catassi C, Montanari MP, Varaldo PE, Nichols BL 1990 Preliminary study of breastfeeding and bacterial adhesion to uroepithelial cells. Lancet 335:569-571

32. Newburg DS 1999 Human milk glycoconjugates that inhibit pathogens. Curr Med Chem 6:117-127

33. Klein N, Schwertmann A, Peters M, Kunz C, Strobel S 2000 Immunomodulatory effects of breast milk oligosaccharides. Adv Exp Med Biol 478:251-259

34. Kondo N, Kobayashi Y, Shinoda S, Takenaka R, Teramoto T, Kaneko H, Fukao T, Matsui E, Kasahara K, Yokoyama Y 1998 Reduced interferon gamma production by antigen-stimulated cord blood mononuclear cells is a risk factor of allergic disorders 6-year follow- up study. Clin Exp Allergy 28:1340-1344

35. Prescott SL, Macaubas C, Smallacombe T, Holt BJ, Sly PD, Loh R, Holt PG 1998 Reciprocal age-related patterns of allergen-specific T-cell immunity in normal vs. atopic infants. Clin Exp Allergy 28(suppl 5):39-44

36. Williams TJ, Jones CA, Miles EA, Warner JO, Warner JA 2000 Fetal and neonatal IL-13 production during pregnancy and at birth and subsequent development of atopic symptoms. J Allergy Clin Immunol 105:951-959

37. Pastorelli G, Rousset F, Pene J, Peronne C, Roncarolo MG, Tovo PA, de Vries JE 1990 Cord blood B cells are mature in their capacity to switch to IgE- producing cells in response to interleukin-4 in vitro. Clin Exp Immunol 82:114-119 